\title{
Kinetics of Immune Response of Indian Major Carps to Sheep Red Blood Cells (SRBC)
}

\author{
B. Kalita ${ }^{1}$, Hemanta Pokhrel ${ }^{1 *}$, C.V. Mohan ${ }^{2}$ and K.M. Shankar ${ }^{3}$ \\ ${ }^{1}$ College of Fisheries, Raha, Assam, India \\ ${ }^{2}$ World Fish, NACA, India \\ ${ }^{3}$ College of Fisheries, Mangalore, India \\ *Corresponding author
}

\section{A B S T R A C T}

Keywords

Indian major carps,

Antibody titers,

Sheep red blood

cells

Article Info

Accepted:

08 June 2018

Available Online:

10 July 2018
The kinetics of primary and secondary immune response of Indian major carps, Catla catla, Labeo rohita and Cirrhinus mrigala to sheep red blood cells (SRBC)were studied in detail at three different age groups of 120,150 and 270 days old. Fish were immunized by injection (i.m) with $10^{6}$ cells/fish of SRBC suspension. The second injection was given at 20 days after the first injection with same dose. All age groups of each species produced detectable humoral antibody titers on $6^{\text {th }}$ days after the first injection. Higher age groups produced higher antibody titers after first as well as second injection. The peak antibody titer was recorded on $9^{\text {th }}$ days after first injection and on $7^{\text {th }}$ day after second injection. The minimum level of antibody titers was recorded on $20^{\text {th }}$ day after first and on $28^{\text {th }}$ day after second injection. The secondary antibody titers were higher to that of the primary antibody titers produced in all three species. The level of antibody titers increased with the age within the species and was significant $(\mathrm{p}<0.05)$. Catla produced higher antibody titers compared to rohu and mrigal after both first and second injection.

\section{Introduction}

Immune response has been studied in several fish species to a variety of antigens including particulate, cellular and molecular. Investigations have shown that teleosts have the immunological capacity to respond to these antigens (1-7). The sera of fish contain naturally occurring antibodies which are lectin like protein (8). Response to bovanine serum albumin (BSA) has been studied in gold fish, Carassius auratus (9), rainbow trout, Salmo gairdneri (10), carp, Cyprinus carpio (11),
dace,Lucious leucious (12) and tilapia, Tilapia mossambica (13). Horse blood cells (HRBC) were studied in lamprey, Lampetra resissneri (1-4) and in summer flounder, Paralicthys dentatus (15). The sheep red blood cells (SRBC) has been shown to elicit a good plaque forming cells and humoral response in rainbow trout, Salmo gairdneri (16), tilapia, Tilapia mossambica (17), flounder, Paralicthys dentalus, Scopholhalmous aquosus and Pseudopleuronectes americanus (18) and carp, Cyprinus carpio (19). The dependence of temperature on the immune 
response of poiklothermic vertebrates has been studied and reviewed (20). In the present study investigation has been carried out to know the kinetics of primary and secondary humoral antibody response to sheep red blood cells (SRBC) at different age groups of three species of Indian major carps catla, rohu and mrigal.

\section{Materials and Methods}

Fish: Hatchlings (4 day old) of Indian major carp, Catla catla, Labeo rohita and Cirrhinus mrigala belonging to a particular brood stock were collected from Bhadra Fish Seed Farm (Karnataka) and maintained at the college fish farm (Mangalore).

Fish were fed daily and were segregated at interval and stocked in identical condition for one year. Four age groups $(120,150,210,270$ days old) of each species were used for experimental purpose and average length and weight of different age groups are given (Table 1).

Antigen: The sheep red blood cells (SRBC) were collected from butcher shop in haperinzed glass beaker and harvested by centrifugation at $2000 \mathrm{rpm}$ for 10 minutes and washed three times by centrifugation with sterile phosphate buffered saline ( $\mathrm{pH}$ 7.2). Cells were counted using haemocytometer and required dilution was made shortly before use for the experiment.

Immunization: 50 numbers of fish from each age group were acclimatized for 7 days in experimental cement cisterns. Fish were injected with $0.1 \mathrm{ml}$ of $10^{6}$ cells/fish of sheep red blood cells suspension and control group received $0.1 \mathrm{ml}$ of phosphate buffered saline. Fish were released back into the cisterns and maintained for 7 weeks. The second dose of injection was given at 20 days after the first injection with same dose.
Haemoagglutination test: Serum antibody analyses were made individually on 6, 9, 15 and 20 days after first and weekly intervals up to 28 days after second injection. Blood was drawn and stored over night at $40^{\circ} \mathrm{C}$ and serum was separated by centrifugation at 6000-7000 rpm for 10 minutes. Serums were inactivated at $50^{\circ} \mathrm{C}$ for 30 minutes in water bath. Haemoagglutination titration was performed by micro titer using serial two-fold dilution and titer values were expressed as $\log _{2}$ dilution.

\section{Results and Discussion}

The erythrocyte antigen has been widely used to demonstrate adoptive immunity in fish. The kinetics of the primary and secondary antibody response to SRBC antigen in different age groups of Indian major carps, catla (Catla catla), rohu (Labeo rohita) and mrigal (Cirrhinus mrigala) is given (Table 2, 3 and 4). Catla, rohu and mrigal produced antibody response against SRBC antigen. The peak primary antibody titers recorded in catla on day 9 after first injection were $3.80 \pm 0.20$, $4.33 \pm 0.33,4.80 \pm 0.28,5.00 \pm 0.57$; in rohu $2.33 \pm 0.31,4.00 \pm 0.57,4.25 \pm 0.62,4.33 \pm$ 0.33 and in mrigal $3.13 \pm 0.33,3.80 \pm 0.58$, $4.50 \pm 0.50,4.66 \pm 0.33$ in $120,150,210$ and 270 day age groups respectively. Higher age groups of fish showed higher level of antibody titers within the species (Table 2, 3 and 4). Sailendri and Muthukkaruppan (13) recorded peak antibody titer on day 9 after priming in Tilapia mossambica against SRBC given intravenously; while, Stolen et al(18)observed peak antibody titer 20 days after priming against SRBC by i. p. injection in three species of flounder. It is well known that the route of administration and dose of antigen (21), nature of antigen (18) and temperature (22) have prominent effect on humoral response in fish. In this study, a medium dose of $10^{5}$ cells/fish was injected by i. m. which could produce significant antibody titers in all the age groups of the three species. 
Table.1 Average length weight of Indian Major carps of different age groups of Indian Major Carps

\begin{tabular}{|c|c|c|c|c|c|c|}
\hline Days & \multicolumn{2}{|c|}{ Catla catla } & \multicolumn{2}{c|}{ Labeo rohita } & \multicolumn{2}{c|}{ Cirrhinus mrigala } \\
\hline & $\begin{array}{c}\text { Length }(\mathrm{cm} \pm \\
\text { S.E.) }\end{array}$ & Weight $(\mathrm{g} \pm$ S.E. $)$ & Length $(\mathrm{cm} \pm$ S.E.) & Weight $(\mathrm{g} \pm$ S.E.) & \multicolumn{2}{c|}{$\begin{array}{c}\text { Length }(\mathrm{cm} \pm \\
\text { S.E.) }\end{array}$} \\
\hline $\mathbf{1 2 0}$ & $12.80 \pm 1.22$ & $24.42 \pm 0.81$ & $13.10 \pm 0.75$ & $21.12 \pm 0.42$ & $13.15 \pm 2.39$ & $20.15 \pm 0.43$ \\
\hline $\mathbf{1 5 0}$ & $14.80 \pm 1.22$ & $43.10 \pm 1.86$ & $14.50 \pm 2.33$ & $35.52 \pm 0.37$ & $14.50 \pm 2.39$ & $28.30 \pm 1.18$ \\
\hline $\mathbf{2 1 0}$ & $19.40 \pm 1.70$ & $83.80 \pm 1.46$ & $17.70 \pm 1.22$ & $71.50 \pm 0.65$ & $17.90 \pm 2.50$ & $66.50 \pm 2.30$ \\
\hline $\mathbf{2 7 0}$ & $23.40 \pm 1.87$ & $163.00 \pm 3.74$ & $21.62 \pm 3.75$ & $138.40 \pm 3.23$ & $23.00 \pm 2.66$ & $130.00 \pm 4.00$ \\
\hline
\end{tabular}

Table.2 Antibody titer $\left(\log _{2}\right)$ in Catla catla of different age groups injected with SRBC antigen

\begin{tabular}{|c|c|c|c|c|c|c|c|c|c|}
\hline \multirow{3}{*}{$\begin{array}{l}\text { Age group } \\
\text { (days) }\end{array}$} & \multirow{3}{*}{$\begin{array}{c}\text { Test } \\
\text { group }\end{array}$} & \multicolumn{8}{|c|}{ Humoral antibody titer } \\
\hline & & \multicolumn{4}{|c|}{ Days after first injection } & \multicolumn{4}{|c|}{ Days after second injection* } \\
\hline & & 6 & 9 & 15 & 20 & 7 & 14 & 21 & 28 \\
\hline \multirow{2}{*}{120} & I & $2.00 \pm 0.73$ & $3.80 \pm 0.20$ & $2.33 \pm 0.33$ & $1.75 \pm 0.47$ & $5.00 \pm 0.70$ & $3.50 \pm 0.50$ & $3.00 \pm 0.40$ & $2.16 \pm 0.16$ \\
\hline & $\mathrm{C}$ & $0.25 \pm 0.25$ & $0.28 \pm 0.18$ & $0.33 \pm 0.33$ & $0.60 \pm 0.66$ & $0.50 \pm 0.50$ & $0.20 \pm 0.20$ & $1.00 \pm 0.57$ & $0.33 \pm 0.33$ \\
\hline \multirow{2}{*}{150} & I & $3.20 \pm 0.48$ & $4.33 \pm 0.33$ & $2.66 \pm 0.33$ & $2.80 \pm 0.20$ & $5.16 \pm 0.16$ & $3.75 \pm 0.25$ & $3.66 \pm 0.66$ & $2.80 \pm 0.20$ \\
\hline & $\mathrm{C}$ & $1.00 \pm 0.57$ & $0.25 \pm 0.25$ & $0.66 \pm 0.66$ & $0.83 \pm 0.40$ & $0.60 \pm 0.44$ & $0.25 \pm 0.25$ & $0.40 \pm 0.27$ & $0.25 \pm 0.25$ \\
\hline \multirow{2}{*}{210} & I & $3.75 \pm 0.48$ & $4.80 \pm 0.28$ & $3.66 \pm 0.66$ & $3.00 \pm 0.57$ & $6.00 \pm 0.40$ & $4.00 \pm 0.40$ & $3.75 \pm 0.25$ & $2.75 \pm 0.47$ \\
\hline & $\mathrm{C}$ & $0.60 \pm 0.40$ & $0.83 \pm 0.40$ & $0.33 \pm 0.33$ & $0.60 \pm 0.40$ & $0.75 \pm 0.47$ & $0.25 \pm 0.25$ & $0.60 \pm 0.33$ & $0.20 \pm 0.20$ \\
\hline \multirow{2}{*}{270} & I & $4.33 \pm 0.33$ & $5.00 \pm 0.57$ & $4.00 \pm 0.31$ & $3.33 \pm 0.33$ & $6.25 \pm 0.25$ & $4.33 \pm 0.66$ & $4.00 \pm 0.57$ & $3.50 \pm 0.28$ \\
\hline & $\mathrm{C}$ & $0.50 \pm 0.22$ & $0.33 \pm 0.33$ & $0.50 \pm 0.28$ & $0.83 \pm 0.54$ & $0.20 \pm 0.20$ & $0.40 \pm 0.24$ & $0.25 \pm 0.25$ & $0.40 \pm 0.24$ \\
\hline
\end{tabular}

*Second injection given on day 20 after first injection

I= Immunized

$\mathrm{C}=$ Control 
Table.3 Antibody titer $\left(\log _{2}\right)$ in Labeo rohita of different age groups injected with SRBC antigen

\begin{tabular}{|c|c|c|c|c|c|c|c|c|c|}
\hline \multirow{3}{*}{$\begin{array}{l}\text { Age group } \\
\text { (days) }\end{array}$} & \multirow{3}{*}{$\begin{array}{c}\text { Test } \\
\text { group }\end{array}$} & \multicolumn{8}{|c|}{ Humoral antibody titer } \\
\hline & & \multicolumn{4}{|c|}{ Days after first injection } & \multicolumn{4}{|c|}{ Days after second injection* } \\
\hline & & 6 & 9 & 15 & 20 & 7 & 14 & 21 & 28 \\
\hline 120 & $\begin{array}{l}\mathrm{I} \\
\mathrm{C}\end{array}$ & $\begin{array}{l}1.80 \pm 0.20 \\
0.20 \pm 0.20\end{array}$ & $\begin{array}{l}2.33 \pm 0.31 \\
0.20 \pm 0.11\end{array}$ & $\begin{array}{l}1.66 \pm 0.38 \\
0.20 \pm 0.20\end{array}$ & $\begin{array}{l}1.33 \pm 0.66 \\
0.25 \pm 0.25\end{array}$ & $\begin{array}{l}3.85 \pm 0.63 \\
0.50 \pm 0.28\end{array}$ & $\begin{array}{l}2.81 \pm 0.81 \\
0.33 \pm 0.23\end{array}$ & $\begin{array}{l}2.00 \pm 0.40 \\
0.25 \pm 0.25\end{array}$ & $\begin{array}{l}1.40 \pm 0.97 \\
0.20 \pm 0.20\end{array}$ \\
\hline 150 & $\begin{array}{l}\mathrm{I} \\
\mathrm{C}\end{array}$ & $\begin{array}{l}3.33 \pm 0.88 \\
0.50 \pm 0.28\end{array}$ & $\begin{array}{l}4.00 \pm 0.57 \\
0.66 \pm 0.65\end{array}$ & $\begin{array}{l}2.57 \pm 0.86 \\
0.50 \pm 0.14\end{array}$ & $\begin{array}{l}2.00 \pm 0.40 \\
0.40 \pm 0.24\end{array}$ & $\begin{array}{l}4.66 \pm 0.37 \\
0.66 \pm 0.66\end{array}$ & $\begin{array}{l}3.00 \pm 0.83 \\
0.60 \pm 0.44\end{array}$ & $\begin{array}{l}2.66 \pm 0.80 \\
0.33 \pm 0.33\end{array}$ & $\begin{array}{l}1.60 \pm 0.75 \\
0.25 \pm 0.25\end{array}$ \\
\hline 210 & $\begin{array}{l}\text { I } \\
\text { C }\end{array}$ & $\begin{array}{l}3.50 \pm 0.28 \\
0.60 \pm 0.24\end{array}$ & $\begin{array}{l}4.25 \pm 0.62 \\
0.40 \pm 0.24\end{array}$ & $\begin{array}{l}2.75 \pm 0.62 \\
0.33 \pm 0.33\end{array}$ & $\begin{array}{l}2.33 \pm 0.42 \\
0.60 \pm 0.24\end{array}$ & $\begin{array}{l}4.75 \pm 0.35 \\
0.33 \pm 0.33\end{array}$ & $\begin{array}{c}3.33 \pm 0.83 \\
0.80 \pm 0.37\end{array}$ & $\begin{array}{l}2.75 \pm 0.62 \\
0.66 \pm 0.66\end{array}$ & $\begin{array}{l}2.40 \pm 0.67 \\
0.25 \pm 0.25\end{array}$ \\
\hline 270 & $\begin{array}{l}\text { I } \\
\text { C }\end{array}$ & $\begin{array}{l}3.60 \pm 0.67 \\
0.75 \pm 0.47\end{array}$ & $\begin{array}{l}4.33 \pm 0.33 \\
0.25 \pm 0.25\end{array}$ & $\begin{array}{c}3.00 \pm 0.33 \\
0.25 \pm 0.25\end{array}$ & $\begin{array}{l}2.50 \pm 0.28 \\
0.40 \pm 0.37\end{array}$ & $\begin{array}{c}5.40 \pm 0.44 \\
0.60 \pm 0.24\end{array}$ & $\begin{array}{l}3.50 \pm 0.50 \\
0.33 \pm 0.37\end{array}$ & $\begin{array}{l}2.75 \pm 0.62 \\
0.41 \pm 0.24\end{array}$ & $\begin{array}{l}2.66 \pm 0.33 \\
0.50 \pm 0.28\end{array}$ \\
\hline
\end{tabular}

*Second injection given on day 20 after first injection

I= Immunized

$\mathrm{C}=$ Control

Table.4 Antibody titer $\left(\log _{2}\right)$ in Cirrhinus mrigala of different age groups injected with SRBC antigen

\begin{tabular}{|c|c|c|c|c|c|c|c|c|c|}
\hline \multirow{3}{*}{$\underset{\text { (days) }}{\text { Age group }}$} & \multirow{3}{*}{$\begin{array}{c}\text { Test } \\
\text { group }\end{array}$} & \multicolumn{8}{|c|}{ Humoral antibody titer } \\
\hline & & \multicolumn{4}{|c|}{ Days after first injection } & \multicolumn{4}{|c|}{ Days after second injection* } \\
\hline & & 6 & 9 & 15 & 20 & 7 & 14 & 21 & 28 \\
\hline \multirow[b]{2}{*}{120} & I & $1.75 \pm 0.62$ & $3.13 \pm 0.33$ & $2.20 \pm 0.37$ & $1.40 \pm 0.50$ & $4.00 \pm 0.70$ & $3.50 \pm 0.32$ & $2.20 \pm 0.20$ & $1.75 \pm 0.25$ \\
\hline & $\mathrm{C}$ & $0.20 \pm 0.20$ & $0.50 \pm 0.22$ & $0.40 \pm 0.24$ & $0.25 \pm 0.25$ & $0.60 \pm 0.33$ & $0.33 \pm 0.33$ & $0.20 \pm 0.20$ & $0.20 \pm 0.20$ \\
\hline \multirow[b]{2}{*}{150} & I & $2.87 \pm 0.12$ & $3.80 \pm 0.58$ & $2.75 \pm 0.62$ & $2.25 \pm 0.25$ & $4.33 \pm 0.66$ & $3.66 \pm 0.80$ & $3.20 \pm 0.20$ & $2.40 \pm 0.24$ \\
\hline & $\mathrm{C}$ & $0.40 \pm 0.24$ & $0.60 \pm 0.44$ & $0.25 \pm 0.25$ & $0.20 \pm 0.20$ & $0.33 \pm 0.33$ & $0.60 \pm 0.40$ & $0.40 \pm 0.24$ & $0.33 \pm 0.33$ \\
\hline \multirow[b]{2}{*}{210} & I & $3.66 \pm 0.33$ & $4.50 \pm 0.50$ & $3.50 \pm 0.32$ & $2.50 \pm 0.50$ & $4.80 \pm 0.20$ & $3.75 \pm 0.47$ & $3.25 \pm 0.25$ & $2.57 \pm 0.29$ \\
\hline & $\mathrm{C}$ & $0.57 \pm 0.36$ & $0.60 \pm 0.40$ & $0.42 \pm 0.29$ & $0.28 \pm 0.18$ & $0.28 \pm 0.18$ & $0.37 \pm 0.26$ & $0.28 \pm 0.15$ & $0.25 \pm 0.16$ \\
\hline \multirow[b]{2}{*}{270} & I & $3.75 \pm 0.25$ & $4.66 \pm 0.33$ & $4.00 \pm 0.40$ & $2.81 \pm 0.81$ & $5.60 \pm 0.24$ & $4.00 \pm 0.57$ & $3.50 \pm 0.67$ & $3.00 \pm 0.83$ \\
\hline & $\mathrm{C}$ & $0.25 \pm 0.25$ & $0.40 \pm 0.24$ & $0.66 \pm 0.44$ & $0.33 \pm 0.33$ & $0.50 \pm 0.22$ & $0.22 \pm 0.20$ & $0.33 \pm 0.33$ & $0.20 \pm 0.20$ \\
\hline
\end{tabular}

*Second injection given on day 20 after first injection

I= Immunized; $\mathrm{C}=$ Control 
The nature of antigen also has prominent on the humoral immune response and was reported that immunogenicity of different antigens differs between the species (18). Horse erythrocyte blood cells (HRBC) were good immunogen in winter flounder, while SRBC were not; however, SRBC were good immunogens in carp (23). In the present study, SRBC worked as a good immunogen in the three species of Indian major carps by producing humoral antibody titers, but there were differences in the magnitude of humoral responses among the species. This is possibly due to species specific differences or the effectiveness of a particular erythrocyte antigen which may vary between species.

The peak secondary antibody titer was recorded on day 7 after second injection were $5.00 \pm$ $0.70,5.16 \pm 0.16,6.50 \pm 0.40,6.25 \pm 0.25$; in rohu $3.85 \pm 0.63,4.66 \pm 0.37,4.75 \pm 0.35,5.40$ \pm 0.44 and in mrigal $4.00 \pm 0.70,4.33 \pm 0.66$, $4.80 \pm 0.20,5.60 \pm 0.24$ in $120,150,210$ and 270 day age group respectively. Higher levels of antibody titers were recorded in older age groups in all the three species (Table 2, 3 and $4)$. The level of antibody titer increased with age within the species and was significant $(p<0.05)$ in all the three species. Increased antibody titers was reported in tilapia (13), common carp (20) and marine teleost, Paralichthys dentalis (15). Rijkers et al., (24) showed that secondary enhancement of humoral immune response to SRBC was dependent and the priming route was important for the magnitude of response. They also reported that low and medium doses of SRBC were more effective in the induction of memory. The route of administration and dose of SRBC in this study were same for the first as well as second injection and produced enhanced antibody titers compared to primary antibody titers after second injection. Though, the route and dose were same for all the groups, humoral antibody titers increased with increase in age/size of the fish, which clearly indicates the effect of age/size on the humoral immune response in the species of Indian major carps.
From the study, it is clear that the three species of Indian major carps of age 4, 5,7 and 9 months can mount humoral immune response and immunological maturation occurs at 1-2 months after hatching(7). This observation is in agreement with that of report made by Sailendri and Muthukkaruppan (13) in Tilapia mossambica where adult tilapia of 2.5, 3.0 and 4.5 month age could mount both humoral and cellular responses and reported that immunological maturation took place at the age of 1-2 months after hatching.

\section{References}

Avtalin RR, Wojdani A, Sharabani R,Duczymirer M(1973) Influence of environmental temperature on the immune response in fish. Current Topics Microbiol. Immunol. 61:1-35.

Avtalion RR (1969) Temperature effect on antibody production and immunological memory in carp (Cyprinus carpio) immunized against bovine serum albumin (BSA). Immunology 17:927938.

Azad, IS, Shankar, KM, Mohan, CV and Kalita, B (1999) Biofilm vaccine of Aeromonas hydrophila,- Standardization of dose and duration for oral vaccination of carps, Fish and Shellfish Immunology, 9: 519-528.

Chiller JM, Hogins HO, Weiser RS (1969) Antibody response in rainbow trout (Salmo gairdneri). II. Studies on the kinetic development, antibodyproducing cells on complement and natural haemolysin. J Immunol.102: 1202-1207

Grondel JL, Nouws JFM, van Muiswinkel WB (1987) The influence of antibiotics on the immune system:immunopharmokineunasagtic investigations on the primary anti SRBC response in carp, Cyprinus carpio L. after oxytetracycline injection. J Fish Diseases. 10:5-45.

Harris JE (1973) The immune response dac, Leuciscus leuciscus to injected antigenic materials. Fish Biol 5: 261-276. 
Hodgins HO, Weiser RS, Ridgway GJ (1967) The nature of antibodies and the immune response in rainbow trout (Salmo gairdneri). J Immunol 99:534544.

Ingram G (1980) Substances involved in natural resistance of fish infection. A review. J Fish Biol 16: 23-60.

Jayaraman S,Mohan M, Muthukkaruppan VR (1979) Relationship between migration inhibition and plaque- forming cells response in sheep erythrocytes in the teleost, Tilapia mossambica. Dev Comp Immunol 7: 76-76.

Kalita B, Mohan CV, Shankar KM, Azad IS (2006) Humoral and protective response of Indian major carps to immersion vaccination with Aeromonas hydrophila. J Indian Fish Assoc 33: 161-168.

Kauranasagar I, Rosland G, Karnasagar I (1991) Immunological response of the Indian major carps to Aeromonas hydrophila vaccine. J Fish Diseases 14: 413-417.

Kidder GM, Ruben IN,Steven JM (1973) Cytodynamics and ontogeny of the immune response of Xenopas laevis against sheep erythrocytes. J Embryol Exp Morph 29:7-85.

Lamers CHJ, Pilarczyk K (1982) Immune response and antigen localization in carp (Cyprinus carpio) after administration of Yersinia ruckeri Oantigen. Dev Comp Immunol Suppl 2: 107-113.

Lamers CHJ, van Muiswinkel WB (1985) The fate of intrperitoneally injectd carbon particles in cyprinid fish. Cell Tissue Res 42: 499-503.

Rijkers GT (1982) Kinetics of humoral and cellular immune reactions in fish. Dev Comp Immunol. Suppl 2:9-100.

Rijkers GT, Frederik-Wlters EMH, van
Muiswinkel WB (1980a) The immune system of cyprinid fish. The effect of antigen dose route administration on the development immunological memory in carp (Cyprinus carpio). In: Manning MJ (ed.) Phylogeny of immunological memory. Elsevier /North Holland Biomedical Press, Amsterdam, pp.93102.

Rijkers GT, Frederix-Walters EMH, van Muiswinkel WB(1980b) The immune system of cyprinid fish: kinetics and temperature dependence of antibody producing cells in carp (Cyprinus carpio). Immunology 41: 91-97.

Sailendri K, Muthukkaruppan VR (1975) Morphology of lymphoid organs in a cichlid teleost, Tilapia mossambica (Peters). J Morpho 147: 109-283.

Smith AM, Potter M,Merchant EB (1767) Antibody -forming cells in the pronephros of the teleost, Lepomis macrochirus. J Immunol 99:876-882.

Stolen JS, Gahn T, Kasper V, Nagle J (1984) The effect of environmental temperature on the immune response of a marine teleost (Paralicthys dentatus). Dev Comp Immunol 8: 89-98.

Stolen S, Gahn T, Nagle J (1982) The humoral antibody formation to erythrocyte antigens in three species of flat fish. Dev Comp Immunol Suppl 2: 101-106.

Tamotsu Fujii, Hiroko Nakagawa, Shinjuro Murakawa (1979). II. Antigen -binding responses to sheep erythrocytes and Hapten in the Ammocoete. Developmental and comparative Immunology 3: 609-620.

Trump GN, Hildemann WH (1970) Antibody response of gold fish to bovine serum albumin. Primary and secondary responses. Immunology 19; 621-627.

\section{How to cite this article:}

Kalita, B., Hemanta Pokhrel, C.V. Mohan and Shankar, K.M. 2018. Kinetics of Immune Response of Indian Major Carps to Sheep Red Blood Cells (SRBC). Int.J.Curr.Microbiol.App.Sci. 7(07): 1204-1209. doi: https://doi.org/10.20546/ijcmas.2018.707.145 